\title{
Investigation on the Access Log Pattern of the Corporate Social Responsibility UUMWiFi among Changlun's Community
}

\author{
https://doi.org/10.3991/ijim.v13i04.10526
}

\author{
Mohamad Farhan Mohamad Mohsin ( ${ }^{\varpi}$, Mohd Noor Abdul Hamid, \\ Nurakmal Ahmad Mustaffa, Razamin Ramli, Kamarudin Abdullah \\ Universiti Utara Malaysia, Sintok, Malaysia \\ farhan@uum.edu.my
}

\begin{abstract}
CSR UUMWiFi is a CSR project under Universiti Utara Malaysia (UUM) that provides unlimited free internet connection for the Changlun community launched in 2015 , the service has accumulated a huge number of users with diverse background and interest. This paper aims to uncover interesting service users' behavior by mining the usage data. To achieve that, the access $\log$ for 3 months with 24,000 online users were downloaded from the WiFi network server, pre-process and analyzed. The finding reveals that there were many loyal users who have been using this service on a daily basissince 2015 and the community spent 20-60 minutes per session. Besides that, the social media and leisure based application such YouTube, Facebook, Instagram, chatting applications, and miscellaneous web applications were among the top applications accessed by the Changlun community which contributes to huge data usage. It is also found that there were few users have used the CSR UUMWiFifor academicor business purposes. The identified patterns benefits the management team in providing a better quality service for community in future and setting up new policies for the service.
\end{abstract}

Keywords - Corporate social responsibility, changlun community, access log, Wi-Fi, wireless network, internet.

\section{$1 \quad$ Introduction}

Internet is an essential medium of communication for many years that has turned this world borderless[1]. As one of the best technology that has been invented so far the performance of Internet is keep improving and brought benefits to human both from developed and developing countries including Malaysia. As we are living in the fourth industrial revolution, countries without or with weak Internet connection will risk the country being left behind. This is the reason for a government to put serious attention to internet infrastructure by providing a broad and sustainable Internet services. These action could benefits the citizen to compete, form a knowledgeable and productive society and improve lifestyle[2].

Malaysia is committed to achieve the status of developed nation. Under the national policy for the communication and multimedia industry, the government has set a plan to establish 
Malaysia as a major global center and hub for communications and multimedia information and content services. Besides that, the government also plans to form Malaysian as a civil society where information-based services will provide the basis of continuing enhancements to quality of work and life [3]. Thus, having the internet as one of the vital ingredients will enable the country to achieve that. Because of that reason, Malaysia is committed to provide the best broadband technologies for many years back that can penetrate the society and reduce the digital divide among Malaysian. This effort has yield a positive impact when the broadband penetration rate in 2017has been increased in all states in comparison with 2016. Table 1 shows the broadband penetration rate per 100 Inhabitant by State (\%) in Malaysia for the year 2016 and 2017[4]. The last column (() depicts the positive internet coverage improvement in every state. In line with this, there were 21.93 million people accessing the internet in Malaysia in 2016 and this figure is projected to grow to 23.41 million in 2022[5].

Table 1. Broadband Penetration Rate per 100 Inhabitant by State (\%) in Malaysia [4]

\begin{tabular}{|l|c|c|c|}
\hline \multicolumn{1}{|c|}{ State } & $\mathbf{2 0 1 7}$ & $\mathbf{2 0 1 6}$ & $\Delta$ \\
\hline W. P. Kuala Lumpur & 225.2 & 191.5 & 33.7 \\
\hline Johor & 148.1 & 130.2 & 17.9 \\
\hline Selangor & 133.8 & 117.4 & 16.4 \\
\hline Pulau Pinang & 130.2 & 105.1 & 25.1 \\
\hline Negeri Sembilan & 128.7 & 95.2 & 33.5 \\
\hline Sarawak & 106.5 & 95.3 & 11.2 \\
\hline Melaka & 103.2 & 86.5 & 16.7 \\
\hline Perak & 102.1 & 84.7 & 17.4 \\
\hline Pahang & 86.4 & 71.7 & 14.7 \\
\hline Kedah & 84.2 & 71.4 & 12.8 \\
\hline Perlis & 83.5 & 71.9 & 11.6 \\
\hline Terengganu & 81.9 & 70.2 & 11.7 \\
\hline W.P. Putrajaya & 78.5 & 77.1 & 1.4 \\
\hline Kelantan & 75.7 & 64.1 & 11.6 \\
\hline W.P. Labuan & 70.3 & 63.1 & 7.2 \\
\hline Sabah & 64.5 & 58.1 & 6.4 \\
\hline Malaysia & 117.3 & 99.8 & 17.5 \\
\hline
\end{tabular}

Realizing the importance of assisting the government to increase ICT literacy among the citizen, especially in the rural areas, Universiti Utara Malaysia (UUM) took an initiative project to provide the Changlun community with free internet connection under its corporate social responsibility (CSR) project called CSR UUMWiFi. Launched in 2015, it is the first a public university who has offered this kind of service that aim to empower and improve the community's quality of life especially the socio-economic and education. To leverage the potential of this technology and ensuring total benefit to the community, UUM also share its knowledge expertise with local community who live along the Sintok-Changlun corridor through an initiative called Changlun Living Lab, in which CSR UUMWiFIacts as the backbone technology. Recently, CSR UUMWiFi provides an unlimited free and direct internet access (i.e. without prior registration)[6]. Since its launching, the service had received huge number of user with diverse background and interest. In previous work of [7], an investigation towards the level of awareness, satisfaction, and the importance of the CSR UUMWiFI were conducted. Finding 
from their survey shows that the service was rated as high in importance bythe local community. However the level of satisfaction towards this service is still at a moderate level.

The CSR UUMWifi uses the cloud technology to store all the network and users activity, which includes their browsing history. The availability of access log information in the server provide an opportunity to investigate the pattern of usage among the Changlun community when they are connected with the CSR UUMWiFi and uncover their interesting behavior while connected to the service. The finding of this study provide useful insights for theUUM management team about quality of the service and will be useful in setting up future plans and policies for improvement. In this study, the access log for 3 months with 24,000 online users were downloaded from the Wi-Fi network server and they were statistically analyzed.

The remainder of the paper is organized as follows: Section 2 outlines the background of UUM SCRWIFI for Changlun community. Section 3 is the methodology on how this study is conducted. Then Section 4 presents the main results. The final section, Section 5, concludes this work.

\section{CSR UUMWiFi For Changlun Community}

Changlun is a township in KubangPasu district about 42 kilometer from state capital AlorSetar and is the nearest town to the UUM. It is located within the state of Kedah, which has one of the lowest broadband penetration in the country(Refer Table 1). The population of the town is made of people from different races, diverse economic and social background with Malays, 583 (38.7\%) Chinese, 86 (5.7\%) Indian, 28 (1.9\%) other Bumiputera and others such as Siamese and $115(7.6 \%)$ Non-Malaysian. Its strategic location near to the Malaysia-Thailand border, has set Changlun as a satellite town for the surrounding areas, such as Napoh, Bukit KayuHitam, Pauh, Kodiang and Arau. The economic and social progress in the area has led to an increase in population, which is evident from the growing number of new developments for residential and commercial areas. The town houses several government agencies, higher education institutions, logistics hub and industrial zone. In line with rapid development, Changluntown has led to an increase in demand for digital services, particularly services that are based on the internet. One of the project is the CSR UUMWiFi.

CSR UUM WiFi is an initiative CSR project under UUM started in 2015that provides a free internet connection to its nearby community. The project covers the Sintok - Changlun Corridor with six hot spot locationswhich are: Bandar BaruSintok Primary and Secondary Schools, UUM staff residential area, C-MART Shopping Complex, Taman Teja Housing Area, and the UUM Big Screen area as shown in Figure 1. The focus of this study is on the three main hot spots locations which; the C-MART Shopping Complex, Taman Teja Housing Area, and the UUM Big Screen area.

CSR UUMWiFi is running on Cisco Meraki Server System and it is operated and maintained by the UUM Information Department (UUMIT) teams. Currently the maximum internet connection is $50 \mathrm{Mbps}$. To ensure the Wi-Fi performs at reasonable speed, UUMIT allocates different number of access points at every hot spot location. Table 3 indicates the access points at three hot spot locations. Since 2015, there were about 50,000 users used this facility with average of 700 users per day. Figure 2 samples the internet usage and internet traffic of the CSR UUM WiFi for 6 months (from June to December 2016). 


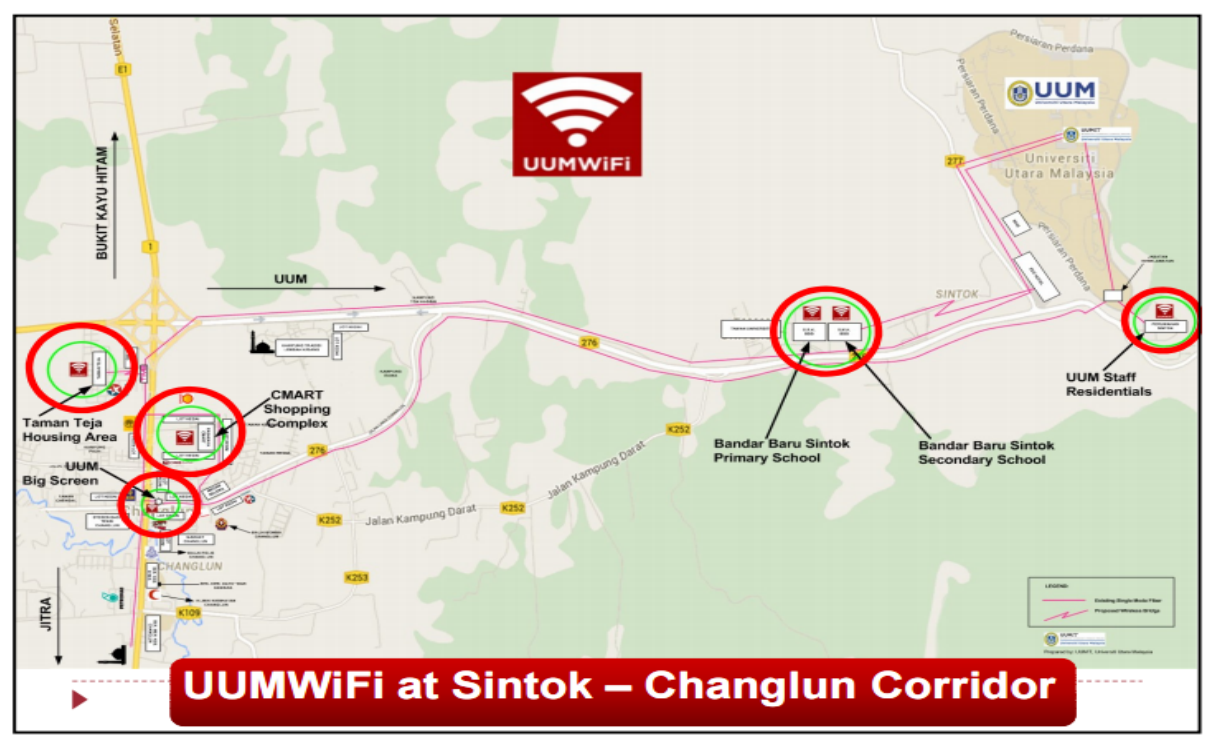

Fig. 1. CSR UUMWiFi hotspots locations

\section{Clients per day}

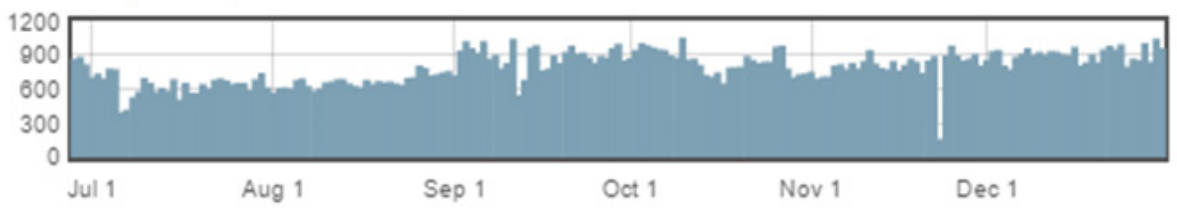

Clients per day

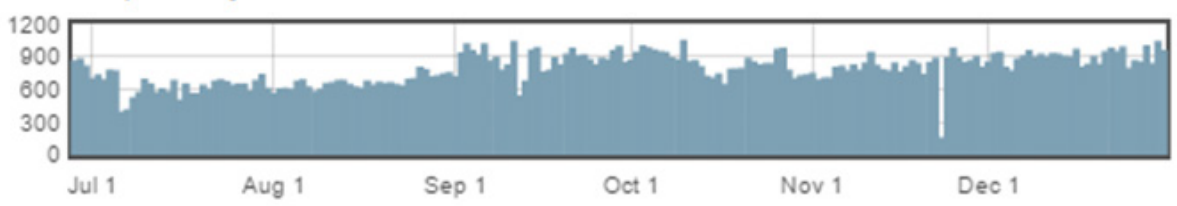

Fig. 2. Internet usage and internet traffic of the CSR UUM WiFi for 6 months (June to Dec 16).

\section{$3 \quad$ Methodology}

The data for this study is obtained from CISCO Meraki server (https://n69.meraki.com/UUM_CSR) that track and store history information about online user who get connected to the CSR UUMWiFi network. The access log information includes the connection period, visited websites and accessed applications, total upload, total download, and access point information. The access $\log$ for the period of 3 months were downloaded from the 
server - 20 October 2016- 20 November 2016 (P1), 20 December 2016 - 20 January 2017(P2), and 23 September 2017- 23 October 2017 (P3). In total, there were 24, 000 records of online users were gathered for analysis. All records were preprocessed and then analyzed using descriptive statistic.

CSR UUMWiFihas 6 hotspot locations. The present study focus on the three main locations with heavy usage which are CMART Shopping Complex, Taman Teja Housing Area, and UUM Big Screen as shown in Figure 3. Each location has different number of access points. The CMART Shopping Complex has more access points as comparison others since it is the main center for Changlun communities to run activities. Table 3 shows the access point name and its location at CMART Shopping Complex, Taman Teja Housing Area, and UUM Big Screen.

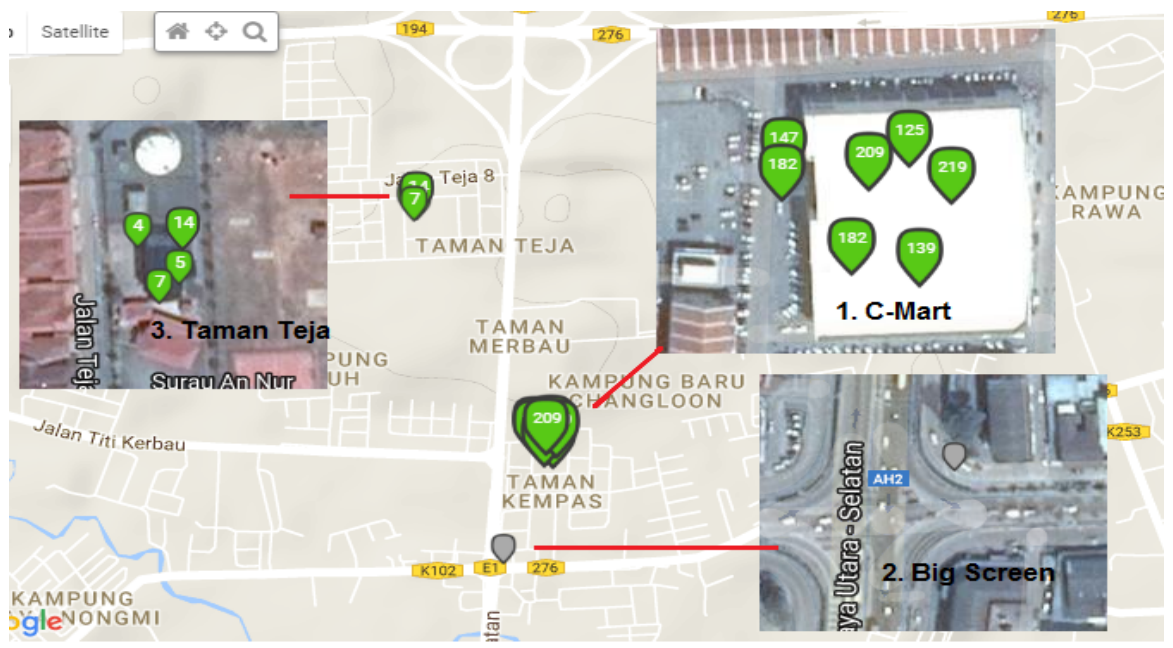

Fig. 3. Three UUMWifi locations; CMART Shopping Complex, Taman Teja Housing Area, and UUM Big Screen and the number of access points

\section{$4 \quad$ Result and Finding}

In this section, the patterns of CSR UUMWiFi usage among the Changlun community were presented based on the three months access log information - P1, P2, and P3. Table 2 shows the total number of connected user and its total usage. As summarized in Table 2, CSR UUMWiFi has huge number of user in every month with the average number of user is 8300 . The total download data per months also indicates a huge volume with more than $920 \mathrm{~GB}$ data were used for download in P1 and P2 while 784.57GB data in P3. Although the number of user in P1 was the lowest in comparison with P2 and P3, its total internet usage was classified among the highest. From Table 2, an early assumption can be made based on the number of user and total usage is that the Changlun community is utilizing the CSR UUMWiFiand benefits them as found in [7]. However, further investigation need to be carried out to further inspect their browsing histories. 
Paper-Investigation on the Access Log Pattern of the Corporate Social Responsibility...

Table 2. Total number of clients and total usage

\begin{tabular}{|c|c|c|c|c|}
\hline & $\begin{array}{c}\text { Data period } \\
\text { (30 days) }\end{array}$ & \# clients & Total usage (GB) & $\begin{array}{c}\text { Average client/total } \\
\text { usage }\end{array}$ \\
\hline P1 & 20 October 2016 - 20 November 2016 & 7675 & 926.59 & 0.1207 \\
\hline P2 & 20 December 2016 - 20 January 2017 & 8616 & 951.17 & 0.1103 \\
\hline P3 & 23 September 2017-23 October 2017 & 8617 & 784.57 & 0.0910 \\
\hline Average & 8302 & 887.44 & 0.1068 \\
\hline
\end{tabular}

Different hotspot locations has different number of users accessing the CSR UUMWiFi. Table 3shows the internet usage and its number of users in P1. As specified in the table, it can be clearly seen that CMart is the most visited hot spot that form $87 \%$ of the total users followed by Big Screen Junction (12\%). There were fewer users in Taman Teja (1\%). This probably due to the fact that this is a residential areas with majority of the residents are working class who may have their own private internet connection at home.

Table 3. The total Wi-Fi usage and its number of user according to access point in P1

\begin{tabular}{|c|c|c|c|c|c|}
\hline$\#$ & Location & Access point \& location & Usage & \# User & $\%$ User \\
\hline 1 & \multirow{7}{*}{$\begin{array}{l}\text { CMARTShopping } \\
\text { Complex }\end{array}$} & CMART_1F_ESCALATOR & $170.27 \mathrm{~GB}$ & 3154 & \multirow{7}{*}{$87 \%$} \\
\hline 2 & & CMART_1F_BOWLING & $142.72 \mathrm{~GB}$ & 2937 & \\
\hline 3 & & CMART_GF_M.ENTRANCE & $139.68 \mathrm{~GB}$ & 3324 & \\
\hline 4 & & CMART_OUTDOOR AP2 & $110.03 \mathrm{~GB}$ & 3684 & \\
\hline 5 & & CMART_OUTDOOR AP1 & $109.57 \mathrm{~GB}$ & 4365 & \\
\hline 6 & & CMART_GF_KMOTOR & $105.25 \mathrm{~GB}$ & 1969 & \\
\hline 7 & & CMART_GF_CASHIER & $91.84 \mathrm{~GB}$ & 3099 & \\
\hline 8 & Big Screen Junction & CSR_BIGSCREEN & $82.81 \mathrm{~GB}$ & 2997 & $12 \%$ \\
\hline 9 & \multirow{2}{*}{ Taman Teja } & T.TEJA_OUTDOOR_AP03 & $42.90 \mathrm{~GB}$ & 171 & \multirow[b]{2}{*}{$1 \%$} \\
\hline 10 & & T.TEJA_OUTDOOR_AP02 & $17.84 \mathrm{~GB}$ & 183 & \\
\hline
\end{tabular}

On the type of application that mostly accessed by the community during P1, P2, and P3, the finding shows that there were more than 90 various web applications accessed by the community. From that number, the top 20 web applications in P1, P2, and P3 were filtered and sorted based on the total number of usage and it is shown in Table 4. It can be clearly seen that CSR UUMWiFi was mostly used for leisure activities that has relation with video and music, social web, and website surfing. The reason is that most of the user were accessing the network in CMART shopping complex where most users normally spend time for their leisure activitiesand not so much for academic purposes.

In Table 4, the users spend most of the time at watching YouTube videos. In P1, P2, and P3 YouTube ranked at the top where the total YouTube usage in P1 was 467.73GB, P2 was 371.19GB, and P3 was 267.10GB. Instead of the YouTube, the user also used CSR UUMWiFi to watch video though miscellaneous website video as found in P2 (11.33GB). Facebook and accessing miscellaneous secure website were among the top applications accessed by the Changlun communities after the YouTube. Both application alternately rank at the second and third. In P1, 101.91GB had been consumed by the users on Facebook and the usage spike to 251.27GB and 213.00GB P2 and P3. Accessing miscellaneous secure website including WhatsApp, Content Delivery Network (CDNs) application based servers, UDP and Non TCP based application, accessing google HTTPS, Google are among the most frequent accessed 
Paper-Investigation on the Access Log Pattern of the Corporate Social Responsibility...

application by Changlun communities. The other application related to music and social web were iTunes, Twitter, Instagram, Snapchat and Tumblr. Instead of leisure based activates, the communities also used the Wi-Fi for web file sharing such Google Drive, iCloud, Dropbox, Media Fire. As highlighted previously, there were very few users who used CSR UUMWiFi for academic or business purposes.

Table 4. The top 20 most accessed application by Changloon Communities in P1, P2

\begin{tabular}{|c|c|c|c|}
\hline$\#$ & Application & Group & $\begin{array}{l}\text { Usage } \\
\text { (GB) }\end{array}$ \\
\hline 1 & YouTube & Video & 467.73 \\
\hline 2 & $\begin{array}{l}\text { Miscellaneous } \\
\text { secure web }\end{array}$ & - & 126.29 \\
\hline 3 & Facebook & $\begin{array}{c}\text { Social } \\
\text { web }\end{array}$ & 101.91 \\
\hline 4 & $\begin{array}{l}\text { Miscellaneous } \\
\text { secure web - } \\
\text { mmg.whatsapp.n } \\
\text { et }\end{array}$ & - & 96.02 \\
\hline 5 & Google HTTPS & - & 55.40 \\
\hline 6 & iTunes & Music & 33.28 \\
\hline 7 & $\begin{array}{l}\text { Miscellaneous } \\
\text { web }\end{array}$ & - & 25.19 \\
\hline 8 & $\mathrm{CDNs}$ & - & 22.50 \\
\hline 9 & Tumblr & - & 19.89 \\
\hline 10 & apple.com & - & 18.61 \\
\hline 11 & UDP & - & 9.57 \\
\hline 12 & Instagram & $\begin{array}{l}\text { Social } \\
\text { web }\end{array}$ & 8.45 \\
\hline 13 & Meraki HTTPS & - & 7.66 \\
\hline 14 & Twitter & $\begin{array}{l}\text { Social } \\
\text { web }\end{array}$ & 6.37 \\
\hline 15 & $\begin{array}{l}\text { Miscellaneous } \\
\text { video }\end{array}$ & Video & 5.58 \\
\hline 16 & Non-web TCP & - & 5.08 \\
\hline 17 & Google Drive & - & 3.40 \\
\hline 18 & Google & - & 2.88 \\
\hline 19 & Mediafire.com & \begin{tabular}{|c|} 
Web \\
file \\
sharing \\
\end{tabular} & 2.09 \\
\hline 20 & Snapchat & $\begin{array}{l}\text { Social } \\
\text { web }\end{array}$ & 1.87 \\
\hline
\end{tabular}

\begin{tabular}{|c|c|c|c|}
\hline \# & Application & Group & $\begin{array}{l}\text { Usage } \\
\text { (GB) }\end{array}$ \\
\hline 1 & YouTube & Video & 371.19 \\
\hline 2 & Facebook & $\begin{array}{l}\text { Social } \\
\text { web }\end{array}$ & 251.27 \\
\hline 3 & $\begin{array}{l}\text { Miscellane- } \\
\text { ous secure } \\
\text { web }\end{array}$ & - & 93.89 \\
\hline 4 & $\begin{array}{l}\text { Google } \\
\text { HTTPS }\end{array}$ & - & 54.21 \\
\hline 5 & UDP & - & 31.84 \\
\hline 6 & iTunes & Music & 24.99 \\
\hline 7 & $\mathrm{CDNs}$ & - & 24.96 \\
\hline 8 & $\begin{array}{l}\text { Miscellane- } \\
\text { ous web }\end{array}$ & - & 18.91 \\
\hline 9 & apple.com & - & 15.09 \\
\hline 10 & $\begin{array}{l}\text { Miscellane- } \\
\text { ous video }\end{array}$ & Video & 11.33 \\
\hline 11 & iCloud & $\begin{array}{l}\text { Online } \\
\text { backup }\end{array}$ & 9.94 \\
\hline 12 & Twitter & $\begin{array}{c}\text { Social } \\
\text { web }\end{array}$ & 7.00 \\
\hline 13 & $\begin{array}{l}\text { Meraki } \\
\text { HTTPS }\end{array}$ & - & 5.97 \\
\hline 14 & $\begin{array}{l}\text { Non-web } \\
\text { TCP }\end{array}$ & - & 5.51 \\
\hline 15 & $\begin{array}{l}\text { Google } \\
\text { Drive }\end{array}$ & - & 4.01 \\
\hline 16 & Tumblr & - & 2.65 \\
\hline 17 & Instagram & $\begin{array}{c}\text { Social } \\
\text { web }\end{array}$ & 2.56 \\
\hline 18 & Dropbox & $\begin{array}{c}\text { File } \\
\text { sharing }\end{array}$ & 2.45 \\
\hline 19 & Google & - & 2.41 \\
\hline 20 & Snapchat & $\begin{array}{l}\text { Social } \\
\text { web }\end{array}$ & 1.77 \\
\hline
\end{tabular}

\begin{tabular}{|c|c|c|c|}
\hline \# & Application & Group & \begin{tabular}{|l}
$\begin{array}{l}\text { Usage } \\
\text { (GB) }\end{array}$ \\
\end{tabular} \\
\hline 1 & YouTube & Video & 276.10 \\
\hline 2 & Facebook & $\begin{array}{l}\text { Social } \\
\text { web }\end{array}$ & 213.00 \\
\hline 3 & $\begin{array}{l}\text { Miscellaneous } \\
\text { secure web }\end{array}$ & - & 81.51 \\
\hline 4 & Google HTTPS & - & 56.93 \\
\hline 5 & $\begin{array}{c}\text { Miscellaneous } \\
\text { secure web - } \\
\text { mmg.whatsapp.n } \\
\text { et }\end{array}$ & - & 29.33 \\
\hline 6 & UDP & - & 21.31 \\
\hline 7 & iTunes & Music & 17.93 \\
\hline 8 & apple.com & - & 9.91 \\
\hline 9 & iCloud & $\begin{array}{l}\text { Online } \\
\text { backup }\end{array}$ & 6.44 \\
\hline 10 & Meraki HTTPS & - & 5.20 \\
\hline 11 & $\begin{array}{l}\text { Miscellaneous } \\
\text { web }\end{array}$ & - & 4.46 \\
\hline 12 & Google & - & 3.59 \\
\hline 13 & Non-web TCP & - & 1.96 \\
\hline 14 & Dailymotion & Video & 1.77 \\
\hline 15 & $\begin{array}{l}\text { Miscellaneous } \\
\text { video }\end{array}$ & Video & 1.73 \\
\hline 16 & microsoft.com & - & 1.39 \\
\hline 17 & $\mathrm{CDNs}$ & - & 1.38 \\
\hline 18 & Twitter & $\begin{array}{c}\text { Social } \\
\text { web }\end{array}$ & 1.16 \\
\hline 19 & $\begin{array}{l}\text { Miscellaneous } \\
\text { audio }\end{array}$ & Music & 1.12 \\
\hline 20 & Dropbox & $\begin{array}{c}\text { File } \\
\text { sharing }\end{array}$ & 0.94 \\
\hline
\end{tabular}


The information in Table 4 is further explored in order to discover the most frequent application (\#frequent) accessed by Changlun community within the three periods of study. The finding is summarized in the Table 5. The definition of the most frequent application is the application is accessed constantly in each month (P1, P2, and P3). From the Table 5, there were 13 applications classified as the most frequent (\#frequent =3); apple.com, CDNs, Facebook, Google, Google HTTPS, iTunes, Meraki HTTPS, miscellaneous secure web, miscellaneous video, miscellaneous web, Twitter, UDP, YouTube. Google Drive that had been accessed constantly in P1, P2, and P3. The other 7 applications such iCloud, Instagram, Non-web TCP, Snapchat, Tumblr and Miscellaneous secure web - mmg.whatsapp.net were considered as frequent when they were accessed twice within 3 months. Besides that, the other applications were rank as less frequent when they only appear once a month. Although the accessed pattern to those applications were categorized as frequent or less frequent, all of the applications were essentially important to the Changlun communities since they were among the top 20 of the highest usage application as displayed in Table 4.

Table 5. The most frequent application accessed by Changlun community within the three experimented months

\begin{tabular}{|c|l|c|c|c|c|}
\hline No & Top Application & P1 & P2 & P3 & \#frequent \\
\hline 1 & apple.com & X & $\checkmark$ & $\checkmark$ & 3 \\
\hline 2 & CDNs & $\checkmark$ & $\checkmark$ & $\checkmark$ & 3 \\
\hline 3 & Dailymotion & & & $\checkmark$ & 1 \\
\hline 4 & lropbox & & $\checkmark$ & & 1 \\
\hline 5 & Facebook & $\checkmark$ & $\checkmark$ & $\checkmark$ & 3 \\
\hline 6 & Google & $\checkmark$ & $\checkmark$ & $\checkmark$ & 3 \\
\hline 7 & Google Drive & $\checkmark$ & $\checkmark$ & & 2 \\
\hline 8 & Google HTTPS & $\checkmark$ & $\checkmark$ & $\checkmark$ & 3 \\
\hline 9 & iCloud & & $\checkmark$ & $\checkmark$ & 2 \\
\hline 10 & Instagram & $\checkmark$ & $\checkmark$ & & 2 \\
\hline 11 & iTunes & $\checkmark$ & $\checkmark$ & $\checkmark$ & 3 \\
\hline 12 & Mediafire.com & $\checkmark$ & & & 1 \\
\hline 13 & Meraki HTTPS & $\checkmark$ & $\checkmark$ & $\checkmark$ & 3 \\
\hline 14 & Microsoft.com & & & $\checkmark$ & 1 \\
\hline 15 & Miscellaneous audio & & & $\checkmark$ & 1 \\
\hline 16 & Miscellaneous secure web & $\checkmark$ & $\checkmark$ & $\checkmark$ & 3 \\
\hline 17 & Miscellaneous secure web - mmg.whatsapp.net & $\checkmark$ & & $\checkmark$ & 2 \\
\hline 18 & Miscellaneous video & $\checkmark$ & $\checkmark$ & $\checkmark$ & 3 \\
\hline 19 & Miscellaneous web & $\checkmark$ & $\checkmark$ & $\checkmark$ & 3 \\
\hline 20 & Non-web TCP & $\checkmark$ & & $\checkmark$ & 2 \\
\hline 21 & Snapchat & $\checkmark$ & $\checkmark$ & & 2 \\
\hline 22 & Tumblr & $\checkmark$ & $\checkmark$ & & 2 \\
\hline 23 & Twitter & $\checkmark$ & $\checkmark$ & $\checkmark$ & 3 \\
\hline 24 & UDP & $\checkmark$ & $\checkmark$ & $\checkmark$ & 3 \\
\hline 25 & YouTube & $\checkmark$ & $\checkmark$ & $\checkmark$ & 3 \\
\hline & Total \#frequent : 1 =5 2=7 3=13 & & & \\
\hline
\end{tabular}

We then tracked whether the Changlun community is loyal to CSR UUMWiFi such that they return to use CSR UUMWiFi services again. Based on the access log in P3, we investigat- 
ed their first encountered with the service (i.e. time\& date)as shows in Table 6.. Based on the figure 2, they were 497 and 1516 users had used the services since 2015 and 2016. In 2017, there were 2187 returned users who use CSR UUMWiFi from Jan 2017-Sept 2017 while 1194 new users registered the Wi-Fi in Oct 2017 (P3).

Table 6. Users in $\mathrm{P} 3$ and their First Time Seen in CSR UUMWiFi

\begin{tabular}{|c|c|c|c|c|c|}
\hline \multicolumn{2}{|c|}{2015} & \multicolumn{2}{|c|}{2016} & \multicolumn{2}{|c|}{2017} \\
\hline First Seen & \# clients & First Seen & \# clients & First Seen & \# clients \\
\hline March & 41 & Jan & 58 & Jan & 157 \\
\hline April & 35 & Feb & 60 & Feb & 190 \\
\hline May & 36 & March & 88 & March & 130 \\
\hline June & 39 & April & 69 & April & 2 \\
\hline July 2015 & 27 & May & 140 & May & 42 \\
\hline August & 26 & June & 95 & June & 247 \\
\hline Sept & 39 & July & 83 & July & 248 \\
\hline Oct & 80 & August & 107 & August & 229 \\
\hline Nov & 81 & Sept & 226 & Sept & 942 \\
\hline Dec & 93 & Oct & 212 & Oct & 1194 \\
\hline \multirow[t]{3}{*}{ Total } & 497 & Nov & 156 & Total & 3381 \\
\hline & & Dec & 222 & & \\
\hline & & Total & 1516 & & \\
\hline
\end{tabular}

In Table 7, we further investigated the top 5 users in term of the highest usage in P3 and when they first time seen in the network. From Table 7, it clearly seen that most of the heavy users has been loyal to CSR UUMWiFi since 2015 and 2016. Figure 2 shows the number of users according to categorization of users; occasional, weekly, daily and first time during P3 period.

Table 7. The top 5users in term of total usage and the first time seen in CSR UUMWiFi (P3)

\begin{tabular}{|c|l|c|l|}
\hline$\#$ & \multicolumn{1}{|c|}{ Last seen } & Total Usage (GB) & \multicolumn{1}{c|}{ First seen } \\
\hline 1 & $23 / 10 / 201712: 54$ & 39.62 & $19 / 10 / 201617: 11$ \\
\hline 2 & $23 / 10 / 201712: 21$ & 27.88 & $24 / 2 / 201710: 55$ \\
\hline 3 & $22 / 10 / 201720: 02$ & 22.21 & $29 / 5 / 201715: 03$ \\
\hline 4 & $21 / 10 / 201721: 52$ & 21.34 & $3 / 5 / 201611: 37$ \\
\hline 5 & $23 / 10 / 201712: 55$ & 20.43 & $3 / 11 / 201510: 57$ \\
\hline
\end{tabular}

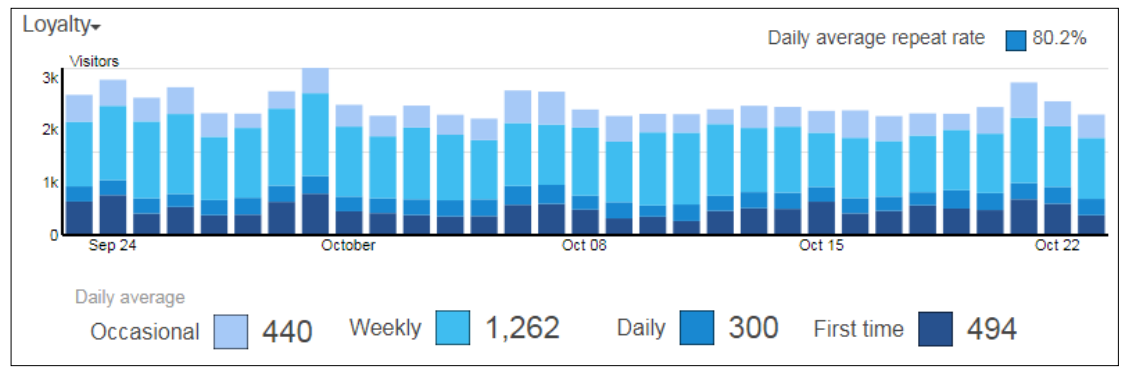

Fig. 4. The number of users according to categorization of users during P3 
In the next analysis, we investigated the total amount of time Changlun community spend in CSR UUMWiFi. Table 8 shows the number of users according to time spent on the service; 520 minutes, 20-60 minutes, 1-6 hours, or more than 6 hours with CSR UUMWiFi in P3. The ' $\mathrm{W}$ ' symbol in Table 8 represents "Win" indicates the winner of the highest users online between 5-20 minutes, 20-60 minutes, 1-6 hours, or more than 6 hours. From the table, most of Changlun communities spent around 20-60 minutes in the network when the highest number of online users can be seen in this group. It was followed by 5-20 minutes online. Besides that, there were also avid users who spent more than 6 hours in CSR UUMWiFi whom most probably are workers at the CMart Shopping Complex or the nearby outlets.

Table 8. The number of users according to time of spend with CSR UUMWiFi in P3

\begin{tabular}{|c|c|c|c|c|c|c|c|c|c|}
\hline Date (2017) & 5-20 mins & $\begin{array}{c}20-60 \\
\text { mins }\end{array}$ & 1-6 hrs & $6+\mathrm{hrs}$ & $\begin{array}{c}\text { Date } \\
(2017)\end{array}$ & $5-20$ mins & $\begin{array}{l}20-60 \\
\text { mins }\end{array}$ & 1-6 hrs & 6+ hrs \\
\hline $23 \mathrm{Sept}$ & 966 & $1116^{\mathrm{w}}$ & 497 & 97 & 9 Oct & $969^{w}$ & 890 & 332 & 82 \\
\hline 24 Sept & 1114 & $1354^{\mathrm{w}}$ & 405 & 92 & $10 \mathrm{Oct}$ & $996^{w}$ & 920 & 306 & 91 \\
\hline $25 \mathrm{Sept}$ & 1047 & $1128^{\mathrm{w}}$ & 358 & 89 & 11 Oct & $974^{w}$ & 934 & 314 & 85 \\
\hline $26 \mathrm{Sept}$ & 1055 & $1257^{\mathrm{w}}$ & 413 & 97 & 12 Oct & $1009^{w}$ & 959 & 361 & 73 \\
\hline 27 Sept & 961 & $998^{w}$ & 286 & 81 & 13 Oct & $991^{\mathrm{w}}$ & 992 & 396 & 89 \\
\hline $28 \mathrm{Sept}$ & $966^{w}$ & 941 & 318 & 93 & 14 Oct & 961 & $1045^{\mathrm{w}}$ & 362 & 78 \\
\hline 29 Sept & 972 & $1170^{\mathrm{w}}$ & 510 & 93 & $15 \mathrm{Oct}$ & 975 & $988^{\mathrm{w}}$ & 327 & 81 \\
\hline 30 Sept & 1197 & $1413^{\mathrm{w}}$ & 491 & 90 & 16 Oct & $983^{w}$ & 970 & 354 & 73 \\
\hline $1 \mathrm{Oct}$ & 1016 & $1061^{\mathrm{w}}$ & 322 & 87 & 17 Oct & 939 & $940^{w}$ & 303 & 89 \\
\hline $2 \mathrm{Oct}$ & $977^{\mathrm{w}}$ & 962 & 260 & 79 & $18 \mathrm{Oct}$ & 928 & $983^{w}$ & 339 & 72 \\
\hline $3 \mathrm{Oct}$ & $1072^{\mathrm{w}}$ & 1010 & 315 & 74 & 19 Oct & $959^{w}$ & 955 & 321 & 80 \\
\hline 4 Oct & 971 & $928^{w}$ & 331 & 66 & $20 \mathrm{Oct}$ & 1002 & $1044^{\mathrm{w}}$ & 319 & 78 \\
\hline $5 \mathrm{Oct}$ & 915 & $926^{w}$ & 311 & 71 & $21 \mathrm{Oct}$ & 1193 & $1212^{\mathrm{w}}$ & 424 & 84 \\
\hline 6 Oct & 1121 & $1129^{w}$ & 440 & 71 & $22 \mathrm{Oct}$ & 1044 & $1138^{\mathrm{w}}$ & 296 & 76 \\
\hline $7 \mathrm{Oct}$ & 1031 & 1216 & 419 & 71 & 23 Oct & $1007^{\mathrm{w}}$ & 891 & 318 & 84 \\
\hline 8 Oct & $1031^{\mathrm{w}}$ & 998 & 297 & 71 & Total & $W=12$ & $W=18$ & $\mathbf{W}=\mathbf{0}$ & $\mathbf{W}=\mathbf{0}$ \\
\hline
\end{tabular}

Each user leaves a trail behind when they were online. In the next analysis, we experimented the pattern of the top user when they use the internet. The top user is the one who has the highest total usage recorded in a month. Table 9depicts the top 5 users based on the highest data usage. The highest user in $\mathrm{P} 3$ consumed 37.7 GB roughly about 5\% from the total usage in the respective month. This raise some important questions of 1)the applications accessed by the single user which accounted for the huge amount of data, 2)how does this users affect the experience of other users and the overall network performance and 3)whether bandwidth limitation need to be imposed in the future.

Table 9. The ranking of top 5 users in term of the highest usage in P3

\begin{tabular}{|c|l|c|c|c|c|}
\hline$\#$ & \multicolumn{1}{|c|}{ Phone/Pc } & Total Usage & Download & Upload & Usage/month \\
\hline 1 & iPhone & $37.7 \mathrm{~GB}$ & $34.26 \mathrm{~GB}$ & $3.44 \mathrm{~GB}$ & $5 \%$ \\
\hline 2 & iPhone & $26.73 \mathrm{~GB}$ & $21.04 \mathrm{~GB}$ & $5.68 \mathrm{~GB}$ & $3 \%$ \\
\hline 3 & DESKTOP-HHKO5C9 & $21.62 \mathrm{~GB}$ & $19.53 \mathrm{~GB}$ & $2.09 \mathrm{~GB}$ & $3 \%$ \\
\hline 4 & iPhone & $20.23 \mathrm{~GB}$ & $19.11 \mathrm{~GB}$ & $1.12 \mathrm{~GB}$ & $3 \%$ \\
\hline 5 & Xiaomi & $15.64 \mathrm{~GB}$ & $14.81 \mathrm{~GB}$ & $854.5 \mathrm{MB}$ & $2 \%$ \\
\hline
\end{tabular}


The information in Table 10 displays the top 10 applications accessed by the top two rank user in P3. Based on the analysis on the most accessed application and websites, most of the users spend more time on the video and social media based application mainly YouTube, Facebook, and WhatsApp. Interestingly, the number of hours spend of the top applications may reach up for several days. Besides that, they also spent a lot of time for miscellaneous secure web and video.

Table 10.

The top applications accessed by the top users in P3

\begin{tabular}{|c|c|c|c|c|c|c|c|}
\hline$\#$ & Destination & Usage & $\begin{array}{l}\text { Active } \\
\text { time }\end{array}$ & $\#$ & Destination & Usage & $\begin{array}{l}\text { Active } \\
\text { time }\end{array}$ \\
\hline \multirow{10}{*}{ TOP 1} & YouTube & $16.38 \mathrm{~GB}$ & 3.2 days & \multirow{10}{*}{ TOP 2} & Facebook & $7.18 \mathrm{~GB}$ & 3.3 days \\
\hline & Facebook & $11.49 \mathrm{~GB}$ & 4.5 days & & YouTube & $5.71 \mathrm{~GB}$ & 2.4 days \\
\hline & iTunes & $1.84 \mathrm{~GB}$ & 7.9 hours & & Google HTTPS & $4.16 \mathrm{~GB}$ & 3.5 days \\
\hline & apple.com & $1.13 \mathrm{~GB}$ & 25 hours & & iTunes & $1.80 \mathrm{~GB}$ & 11 hours \\
\hline & 157.240 .10 .51 & $590.8 \mathrm{MB}$ & 9 hours & & apple.com & $1.34 \mathrm{~GB}$ & 3.6 days \\
\hline & Google HTTPS & $387.4 \mathrm{MB}$ & 2.8 days & & mmg.whatsapp.net & $310.3 \mathrm{MB}$ & 19 hours \\
\hline & mmg.whatsapp.net & $313.0 \mathrm{MB}$ & 11 hours & & $\begin{array}{l}\text { mmx- } \\
\text { ds.cdn.whatsapp.net }\end{array}$ & $190.7 \mathrm{MB}$ & 9 hours \\
\hline & $\begin{array}{l}\text { mmx- } \\
\text { ds.cdn.whatsapp.net }\end{array}$ & $251.9 \mathrm{MB}$ & 10 hours & & Instagram & $173.3 \mathrm{MB}$ & 11 hours \\
\hline & Instagram & $168.6 \mathrm{MB}$ & 19 hours & & Twitter & $99.4 \mathrm{MB}$ & 2.6 hours \\
\hline & 115.164 .187 .194 & $157.5 \mathrm{MB}$ & 1.2 hours & & pps.whatsapp.net & $77.5 \mathrm{MB}$ & 2.9 hours \\
\hline
\end{tabular}

\section{Conclusion}

This paper discovers the pattern of Changlun community when they were online towards the free internet network under the CSR UUMWiFi project. Through the statistical descriptive analysis towards three months web log history left by Changlun community, several conclusions can be derived. Firstly, CSR UUMWiFi is considerably meet it purpose when the number of Changlun community online and the total data usage per month is high and there are users who regularly used this service since 2015up until now. Moreover, itis found that the users mostly spent time in CSR UUMWiFi for social media or leisure based application such YouTube, Facebook, Instagram, chatting, video, and music. The community also used this facility to seek information from miscellaneous web applications and very less used for academic and business purposes. Since the CSR UUMWiFi is free, unlimited and without registration, it motivates the community to continuously use this service and most of them spend 20-60 minutes in the network. As there are many massive download activities such video by similar users as well as unethical websites, it is required for the authorities to set a quota limit for every user in order to maintain a good bandwidth performance. Besides that, it is important to improve the security such to have registration that required user to log in every time they what to use the service. Furthermore, the access log information will be further experimented using data mining approach in our future work. 


\section{Acknowledgement}

The authors gratefully acknowledge the UUM Generation Scheme Grant for supporting this research project through grant SO 13423.

\section{$7 \quad$ References}

[1] E. G. P. Rubem Pereira, "Future internet: trends and challenges," Int. J. Space-Based Situated Comput., vol. 5, no. 3, pp. 1-10, 2015.

[2] Caroline HaythornthwaiteHaythornthwaite Wellman, the Internet in Everyday Life: An Introduction. Blackwell Publishers Ltd, 2008.

[3] Malaysian Communications and Multimedia Commission, "Internet-Users-Survey-2017," 2017.

[4] Malaysian Communications and Multimedia Commission 2015, "MCMC Annual Report 2016,” 2016. [Online]. Available:

[5] https://www.skmm.gov.my/resources/publications/annual-reports. [Accessed: 25-Apr2018].

[6] T. S. Portal, "Number of internet users in Malaysia from 2015 to 2022," The Statistics Portal. [Online]. Available: https://www.statista.com/statistics/553752/number-of-internetusers-in-malaysia/. [Accessed: 25-Apr-2018].

[7] M. Noor, A. Hamid, N. A. Mustaffa, M. Farhan, M. Mohsin, and R. Ramli, "Living Lab Changlun: A Framework to Engage and Empower the Community by Profiling the CSR UUM WiFi Users," in Proceedings for PersidanganKerjaSosial 2017, 2017.

[8] M. Noor, A. Hamid, N. A. Mustaffa, M. Farhan, M. Mohsin, and R. Ramli, "CSR UUMWiFi : A University's Effort in Bridging Digital Divide among Rural Community,” J. Telecommun. Electron. Comput. Eng., vol. 10, no. 1, pp. 1-11, 2017.

\section{Authors}

Mohamad Farhan Mohamad Mohsin currently is the Deputy Dean of UUM CAS Student Development \& Alumni Office and a senior lecturer at School of Computing, UUM. He involves with Artificial Intelligent (AI) related research, a part of computer science branch that studies how machine can own intelligent as human (broad AI definition!). At the moment, most of his researches are in anomaly detection and predictive modeling main in climate change studies and outbreak.

Mohd Noor Abdul Hamid is a Ph.D. scholar and currently full-time lecturer at the School of Creative Industry Management and Perform at the Universiti Utara Malaysia. He research interests are in the area of audit and corporate governance, Template Analysis, The concept of Perceived Value and Higher Education Marketing.

NurAkmal Ahmad Mustaffa is a Senior Lecturer at the Department of Decision Science in the School of Quantitative Sciences, Universiti Utara Malaysia. Her area of specialization and research interests include Deterministic and Stochastic Difference, Supply Chain Management, Markov Decision Process, Discrete Event, Disruption Risk, Inventory Management and Control. 
RazaminRamli is a Professor at the Department of Decision Science in the School of Quantitative Sciences, Universiti Utara Malaysia. Her main research interests are in optimization, meta-heuristics, evolutionary algorithms, planning and scheduling problems, and mixed methods. Her also member of the Management Science and Operations Research Society of Malaysia (MSORSM), and also a member of the International Association of Computer Science and Information Technology (IACSIT).

Kamarudin bin Abdullah worked in the industry for more than 30 years in the area of Internet Services, Sales \& Marketing, ICT Consultancy, Project Management, Customer Services and Technology Research. Research in the area of image processing and neural network. Started MIMOS Consulting Group (MCG) in 1996 which among others, focused in the area of providing Security Services and Consultancy Services to the industry. Has led the Smart City initiative and appointed as lead consultant to develop Putrajaya IT Masterplan. Lead the Sales \& Marketing team in JARING Communications SdnBhd including the Project \& Services Management team. Now leading UUM Information Technology (UUMIT), providing IT services to the community in UUM. Major task is to transform IT in the UUM campus in the area of customer services, infrastructure, information systems, analytics and innovation.

Article submitted 2019-02-13. Resubmitted 2019-02-23. Final acceptance 2019-03-12. Final version published as submitted by the authors. 